\title{
A MULHER SITIADA DE CLARICE LISPECTOR: O SERAFIM COXO ${ }^{1}$
}

\section{THE BESIEGED WOMAN BY CLARICE LISPECTOR: THE LAME SERAPHIN $^{2}$}

Thiago Cavalcante Jeronimo*

\begin{abstract}
Resumo: Este artigo propõe discutir o romance A cidade sitiada (1949), de Clarice Lispector, como marcado pelo recurso discursivo nomeado paródia. A autora, vivendo em Berna, sitiada em contexto europeu, situa o seu texto em um molde tradicional de construção narrativa e, ao se valer de figuras do capítulo seis do livro do profeta Isaías, as reconfigura à constituição de sua protagonista, Lucrécia Neves, mulher materializada dentro dos muros da cidade de São Geraldo. O foco das análises privilegia o capítulo quatro da narrativa de Lispector - "A estátua pública" -, tendo como respaldo teórico, além de interpretações da fortuna crítica acerca da obra da ficcionista, textos abalizados ligados às esferas literária e bíblica.
\end{abstract}

Palavras-chave: Clarice Lispector. A cidade sitiada. Livro de Isaías. Paródia. Antiepifania.

\begin{abstract}
This article proposes to discuss Clarice Lispector's novel The besieged city (1949), as marked by the discursive resource named parody. The author, living in Bern, besieged in a European context, places her text in a traditional of narrative construction mold and, using figures from chapter six of the book of the prophet Isaiah, reconfigures them to the constitution of their protagonist, Lucrécia Neves, woman under siege within the walls of the city of São Geraldo. The focus of the analysis endorses chapter four of Lispector's narrative - "The public statue" -, with theoretical support, in addition to interpretations of the critical fortune of the novelist's work and proficient texts linked to the literary and biblical spheres.
\end{abstract}

Keywords: Clarice Lispector. The besieged city. Isaiah. Parody. Antiepiphany.

"Que diria então se pudesse passar, de ver os objetos, a dizê-los... Era o que ela, com paciência de muda, parecia desejar. Sua imperfeição vinha de querer dizer, sua dificuldade de ver era como a de pintar. [...]. Se ao menos estivesse fora de seus muros".

Clarice Lispector, A cidade sitiada

\footnotetext{
${ }^{1} \mathrm{O}$ presente trabalho foi realizado com apoio da Coordenação de Aperfeiçoamento de Pessoal de Nível Superior - Brasil (CAPES) - Código de Financiamento 001.

2 This study was financed in part by the Coordenação de Aperfeiçoamento de Pessoal de Nível Superior - Brasil (CAPES) - Finance Code 001.

* Doutor e Mestre em Letras pela Universidade Presbiteriana Mackenzie, São Paulo, Brasil, com pesquisas voltadas às obras de Clarice Lispector e de Elisa Lispector. Email: <thiagocavalcante@live.com>.
} 
O ano era 1963. A escritora Nélida Piñon, em depoimento concedido ao jornal carioca Correio da Manhã, definiu Clarice Lispector, dentro do panorama da literatura brasileira, como “uma escritora insuperável”. A afirmação da primeira mulher que presidiu a Academia Brasileira de Letras (1996-1997) marca-se com certo grau de perplexidade. Isso porque, mesmo após duas décadas da publicação de Perto do coração selvagem (1943), livro que inaugura a sucessão de romances de Clarice, bem como um novo modo de narrar no panorama da literatura brasileira, ${ }^{3}$ "para vergonha nossa", complementa Piñon, "[Clarice Lispector] ainda não [tinha sido] devida e necessariamente reconhecida" (PIÑON, 1963, p. 7).

O ano é 2020. O centenário de nascimento de Clarice Lispector é celebrado. A escritora que nasceu na Ucrânia - "de passagem” -, como fazia questão de assinalar, chegando ao Brasil com pouco mais de um ano de idade, é reverenciada como uma das grandes autoras do século XX, principal escritora de sua geração em língua portuguesa. ${ }^{4}$

Traduzida em mais de trinta países, em línguas distantes do português como o hebraico, o japonês e o russo, a obra de Clarice Lispector ganhou novo rumo de projeção na última década, sobretudo pelo empenho de professores, críticos, pesquisadores e editores em propagar sua singular produção, acoplado ao poder tecnológico globalizado. Por um lado, o espaço editorial e midiático, com a intenção de ampliar o público leitor concernente à obra da autora, alavanca o nome de Clarice Lispector numa visão estereotipada e mercadológica: assim os epítetos de "Clarice, a autora de frases de autoajuda" - e/ou - "Clarice, a judia perseguida". Por outro lado, frise-se a observação de que a obra de Clarice se desprende dessas nomenclaturas simplórias e reducionistas e não se deixa entrever no âmbito sensacionalista ou de orientações práticas que se destinam à resolução de conflitos pessoais.

\footnotetext{
${ }^{3}$ De acordo com Nádia Battella Gotlib, Perto do coração selvagem “é inaugural não só porque é o primeiro, a ser seguido por outros, mas porque inaugura um novo modo de narrar na literatura brasileira" (GOTLIB, 2019, p. 202).

${ }^{4}$ Marca-se que uma seleção de crônicas de Clarice, publicada em Portugal, com o título de A descoberta do mundo, editora Indícios de Oiro, Lisboa, traz a seguinte informação ao leitor: "Clarice Lispector, uma das maiores, se não a maior escritora de língua portuguesa do século XX” (OS EDITORES apud LISPECTOR, 2004, p. 7).

5 Os livros As palavras de Clarice Lispector (2013), O tempo de Clarice Lispector (2014), organizados por Roberto Corrêa dos Santos, são exemplos mercadológicos e midiáticos que direcioanam obras da autora a frases de efeito. O título Como Clarice Lispector pode mudar sua vida (2017), de Simone Paulino, apresenta um manual de autoajuda ao leitor baseado em fragmentos de livros de Lispector reunidos em agrupamentos de conselhos simplórios, a exemplo de "Como ser feliz" e de "Como aprender a amar". O direcionamento judaico que Benjamin Moser associa à pessoa e à obra de Clarice Lispector desconsidera o senso de aguda criticidade que a autora nutriu para com os postulados do judaísmo: "Sou judia, você sabe. Mas não acredito nessa besteira de judeu ser o povo eleito de Deus”(LISPECTOR apud COUTINHO, 1980, p. 165-170, grifo nosso).
} 
No âmbito religioso, sublinhe-se que a autora de $A$ cidade sitiada recupera em sua produção um diálogo com a esfera religiosa, mas em outra via de leitura, isto é, ao se apropriar do discurso bíblico, a ficcionista "profana" o hipotexto, o texto fonte, à estruturação do tecido narrativo de sua produção. Explica-se: o profano na obra em questão é analisado como aquilo que está "fora do templo", não necessariamente como algo sacrílego. Interpretação que recupera o postulado de Emílio Pimenta, segundo o qual o profano, ao contrário do sagrado, "é o incompleto, o imperfeito, próprios da condição humana" (PIMENTA, 1980, p. 135).

No conjunto da obra de Lispector, A cidade sitiada é, talvez, um dos seus romances menos estudados pela crítica e, de igual modo, um dos menos populares da autora, conforme reconheceu o crítico Carlos Mendes de Sousa: "Um livro que teve uma recepção difícil, lugar de paragem no percurso da autora" (SOUSA, 2013, p. 73). Oportunidades favoráveis que justificam a escolha desse texto, em especial o quarto capítulo da narrativa - "A estátua pública" - como corpus a ser interpretado. Entende-se que Lispector expõe nesse texto símbolos pertencentes à religião judaica, e essa consideração justifica, também, as análises que neste ensaio serão fundamentadas.

O direcionamento interpretativo posto neste estudo recupera a premissa crítica de Antoine Compagnon, para o qual "toda teoria repousa em um sistema de preferências" (COMPAGNON, 2010, p. 43). Registre-se neste ensaio uma inclinação analítica que lê o texto de Clarice Lispector a contrapelo de aspectos reducionistas ou catalogados, a exemplos dos que enxergam uma via acentuadamente judaica ou feminista na escrituração da autora. ${ }^{6}$ Nesse veio, as interpretações emergidas na materialidade deste artigo não se confinam a promover ou a ver a apropriação da escritora para com as temáticas marcadas no livro do profeta Isaías, no âmbito de catalogar a obra da ficcionista como "Clarice, escritora de temática judaica"; ao contrário, reconhece-se que a Bíblia lhe serviu de referencial, contudo, Clarice Lispector, como observado por Nádia Battella Gotlib, não se prende ou se deixa reduzir "numa identidade única, mas se desloca nas muitas vozes de que povoa a sua narrativa" (GOTLIB, 2001, p. 315).

Segundo depoimento de Lispector, gravado no Museu da Imagem e do Som (RJ) em 1976, a ficcionista reconhece que o seu terceiro romance foi um dos seus livros mais difíceis

\footnotetext{
${ }^{6}$ Sugere-se a leitura de alguns trabalhos que questionam os apriorismos que Benjamin Moser e Hèléne Cixous direcionam à obra de Clarice Lispector no âmbito judaico e feminista, respectivamente: "Uma biografia pop: nova edição de livro sobre vida e obra de Clarice Lispector segue repleta de equívocos defendidos por Benjamin Moser", Márcia Lígia Guidin (2017); "Benjamim Moser: quando a luz dos holofotes interessa mais que a ética acadêmcia", de Thiago Cavalcante Jeronimo (2018); O percurso das personagens de Clarice Lispector, de Bernardete GrobLima (2009), e Nem musa, nem medusa: itinerários da escritra em Clarice Lispector, de Lucia Helena (2010).
} 
de escrever. Com distanciamento cronológico, isto é, vinte e sete anos após a publicação do volume, recorda da experiência dessa escrita com a seguinte enunciação:

A cidade sitiada foi, inclusive, um dos meus livros mais difíceis de escrever, porque exigiu uma exegese que eu não sou capaz de fazer. É um livro denso e fechado. Eu estava perseguindo uma coisa e não tinha quem dissesse o que era. San Tiago Dantas abriu o livro, leu e pensou: "Coitada da Clarice, caiu muito". Dois meses depois, ele me contou que, ao ir dormir, quis ler alguma coisa e o pegou. Então ele me disse: "É o seu melhor livro" (LISPECTOR apud SANT’ANNA; COLASANTI, 2013, p. 221).

Sublinhe-se que o termo grifado exegese é comumente associado à interpretação gramatical, histórica, jurídica de textos literários, mas, particularmente, de textos sagrados, ou seja, da Bíblia. A referência que Clarice indica em seu depoimento conflui, entretanto, no sentido do texto ficcional que produziu durante o tempo em que morava na capital suíça, em Berna. A autora reconhece que a dificuldade que teve em escrever e reescrever o romance (“mais de vinte vezes"), se deu porque ela, em certa medida, parodiou sua produção até então publicada, isto é, acentuou um processo linear e plano em sua escrituração, diferenciou sua escrita, sitiou o seu texto à tradicional e dominante estrutura romanesca.

Se, de acordo com Olga de Sá, Clarice Lispector realizou no conjunto de sua obra a paródia de si mesma, "os romances de Clarice dialogam entre si, levando-nos a concluir que ela realizou, às vezes, nos traços de suas personagens, a paródia de si mesma" (SÁ, 1993, p. 181), desdobrando a interpretação da pesquisadora, o texto A cidade sitiada, se espelhado aos romances Perto do coração selvagem e $O$ lustre (1946), deixa-se ver em uma repetição diferente, concernente, sobretudo, à inovação que o primeiro livro da autora suscitou no cenário literário brasileiro em 1943. Dado que a estruturação do seu terceiro romance, em vez de privilegiar o monólogo interior à quebra da ordem casual exterior, "acentuando as oscilações do tempo ficcional ao esgarçamento da ação romanesca e do enredo" (NUNES, 1995, p. 160161), adequa-se ao modo predominante ao qual a produção literária no Brasil se caracterizava: textos que se prendiam, especialmente, às marcas dos romances regionalistas, condicionados à estrutura linear e cronológica de enredo e de personagens.

Ao publicar um livro com esse matiz anacrônico, interpreta-se neste ensaio um posicionamento irônico da autora para com os postulados do conceito tradicional de leitura crítica em que sua estreia literária, por alguns críticos, foi interpretada.

Álvaro Lins, um nome importante na crítica brasileira na época do aparecimento de Clarice Lispector na literatura brasileira, em seu artigo 
intitulado "A experiência incompleta: Clarice Lispector" (1944), reconhece o valor e a originalidade dos textos da autora, mas não aceita os emblemas da nova era: as infidelidades à ordem cronológica dos acontecimentos e as alternâncias no encadeamento das ações constitutivas do discurso [...]. E insiste no fato de que falta, no romance [Perto do coração selvagem], tanto a criação de um ambiente mais definido e estruturado quanto a existência de personagens como seres vivos (GROB-LIMA, 2009, p. 18-19).

Ciente da leitura de Álvaro Lins, fundamentada no conceito tradicional de interpretação crítica, estruturalista e normativa, Clarice Lispector acentuou, irônica e parodicamente, à elaboração de A cidade sitiada, uma resposta à "incompletude" que alguns de seus intérpretes - a exemplo de Lins - atinaram como falha estrutural.

Pondo atenção ao aspecto biográfico de Lispector, sublinhe-se que enquanto escrevia seu terceiro romance, a autora, casada com o diplomata brasileiro Maury Gurgel Valente, passa a viver em Berna, na Suíça. O dado biográfico, em consonância ao teor narrativo de $A$ cidade sitiada, marca-se neste estudo por compactuar com a visão geral da ficção erguida: a autora sitiada no continente europeu ${ }^{7}$, o livro sitiado a aspectos formais concretos, a personagem Lucrécia, protagonista da trama, sitiada interiormente (dentro de si mesma) e exteriormente na cidade de São Geraldo.

Cumpre recuperar as interpretações postas em letras por Olga de Sá e por Nádia Battella Gotlib, nomes relevantes da fortuna crítica de Clarice Lispector, no que conferem à estrutura peculiar de A cidade sitiada na escrituração de sua autora:

Em A cidade sitiada existe uma história, um enredo, e nele, São Geraldo é a cidade sitiada pelo progresso. Mas há um sub-texto latente, em que a cidade sitiada é o texto, a própria escritura de Clarice Lispector. Ela polemiza consigo mesma, faz "variações sobre o mesmo tema", construindo conscientemente a banalização da narrativa. À medida que a cidade se sitia perde o mistério; à medida que a narradora produz esse texto, sitia o seu próprio modo de narrar (SÁ, 1993, p. 71).

Eis o eixo da ação da biografia de Lucrécia: a personagem vive no subúrbio de São Geraldo e vai testando diferentes experiências de vida, representadas metaforicamente, sob a forma alegórica, em cuidada topografia da cidade e arredores (GOTLIB, 2009, p. 321).

A concretude desse romance imprime no macrotexto de Clarice um certo descompasso com os seus textos anteriores, isto é, a topografia marca-se exterior e não interior, o texto,

\footnotetext{
${ }^{7}$ A crônica "Lembranças de uma fonte, de uma cidade", publicada por Clarice Lispector no Jornal do Brasil, em 14 de fevereiro de 1970, é registro importante acerca da vida da autora na Suíça e da criação do romance A cidade sitiada: "Minha gratidão a este livro é enorme: o esforço de escrevê-lo me ocupava, salvava-me daquele silêncio aterrador das ruas de Berna" (LISPECTOR, 1999, p. 270).
} 
perceptivelmente engessado, não expõe fluxo de consciência e nem dá autonomia de fala à personagem. Em verdade, seus sentidos - visão e fala, por exemplo - são materializados no âmbito da incompletude.

A visão de Lucrécia surge grafada na narrativa em estado de alienação. Alguns exemplos: "seu medo era o de ultrapassar o que via" (LISPECTOR, 2019, p. 98.), "tinha medo de ver, num mesmo olhar, um trem e um passarinho" (LISPECTOR, 2019, p. 61), "ela parecia cega" (LISPECTOR, 2019, p. 48), referências que, em certa medida, tornam míope o olhar da personagem e o registra como "um olhar de lado" (LISPECTOR, 2019, p. 60). Lucrécia não olha, espia. Ressalta-se que o verbo "espiar", com seus desdobramentos, é grafado mais de cinquenta vezes no romance: Lucrécia que não sustenta sua visão, é materializada, por exemplo, “espiando tola o que via" (LISPECTOR, 2019, p. 82).

Tais registros, ao sinalizarem a marca da epifania no tecido narrativo do texto clariciano não aludem ao seu sentido habitual, isto é, a epifania entendida como "o relato de uma experiência que a princípio se mostra simples e rotineira, mas que acaba por mostrar toda a força de uma inusitada revelação" (SANT'ANNA, 2013, p. 128), ${ }^{8}$ mas, por outra via de “(in)expressividade”, a epifania condicionada à Lucrécia se consolida no plano da banalização, uma vez que a personagem é estruturada, conforme interpretou Olga de Sá, “distanciando-se das epifanias gloriosas" (SÁ, 1993, p. 58). ${ }^{9}$

Esse afastamento de uma eventual iluminação à autoconscientização - da passagem da ignorância ao conhecimento -, situa e sitia a personagem que "nunca precisara da inteligência, nunca precisara da verdade" (LISPECTOR, 2019, p. 78) à metáfora da estátua pública, título do capítulo em análise e símbolo de sua paralisação tanto na esfera pessoal, quanto na esfera social de suas experimentações.

A imobilidade interior de Lucrécia, marcada pela falta de conhecimento, convoca à tessitura narrativa, também sitiada, à antiepifania, uma epifania corrosiva, parodiada, isto é, atrelada à apreensão de experimentações anuladas, abortadas: “Assim como existe em Clarice toda uma gama de epifanias da beleza e visão, existe também uma outra, de epifanias críticas e corrosivas, epifanias do mole e das percepções decepcionantes" (SÁ, 1979, p. 156).

\footnotetext{
${ }^{8}$ Luciana Stegagno Picchio pontua três referências epifânicas em Clarice Lispector: "Epifania imaginativamente, como revelação através da escritura de algo essencial que inesperadamente se fixa e se torna visível. Epifania criticamente, terminologicamente, como aparição instantânea e transfiguradora, com explícita alusão à estética joyceana. Mas epifania, também, metaforicamente, como advento nas letras brasileiras, tão viçosas de ambientes e de folclore, tão marcadas pelo sol e pelo trópico, de uma escritura mais esquiva e discreta" (PICCHIO, 1989, p. 17).

${ }^{9}$ Olga de Sá pontua que "Lucrécia escapa sempre. Incapaz de epifanias gloriosas, foge quando o perigo delas se anuncia” (SÁ, 1993, p. 55).
} 
Há epifania no capítulo "A estátua pública”, mas é uma epifania infrutífera, esvaziada de iluminações, e que, ao convocar para a narrativa sua efetivação, o faz eivada da paródia. Ou seja, a antiepifania, a paródia da epifania, não evidencia uma mera negação do estrato ideológico, assimilado do discurso a ser referenciado, mas um diálogo diferente para com o texto institucionalizado à sustentação do perfil da personagem que dita a perspectiva do romance. A cidade sitiada recupera o capítulo seis do livro do profeta Isaías, sitiando-o, também, dentro de seus muros.

Por esse ângulo, antes de recuperar o texto sacro em diálogo com o texto clariciano, cumpre contemplar algumas observações acerca do recurso crítico nomeado paródia. Registrese que o conceito de paródia, fonte de vários posicionamentos e de diversas interpretações, sofreu importantes variações ao longo das pesquisas que consideraram o método discursivo em suas análises. ${ }^{10}$ Etimologicamente, porém, o vocábulo remete ao grego, e segundo esclarece Gérard Genette, é assim dividido:

ôdè, que é o canto; para, "ao longo de", "ao lado de"; parôdein, daí parôdia, o que seria (portanto?) o fato de cantar ao lado de, de cantar fora do tom, ou numa outra voz, em contracampo - em contaponto -, ou ainda, cantar num outro tom: deformar, portanto, ou tanspor uma melodia (GENETTE, 2010, p. 26-27).

Massaud Moisés, em Dicionário de Termos Literários, esclarece que a paródia "designa toda composição literária que imita, cômica e satiricamente, o tema e/ou a forma de outra obra" (2004, p. 140). Elucida, ainda, que "o intuito [da paródia] é ridicularizar uma tendência ou estilo que, por qualquer motivo, se torna apreciado ou dominante" (2004, p. 140, grifos nossos). Linda Hutchon, por sua vez, define o engenho discursivo como "a forma intertextual que constitui, paradoxalmente, uma transgressão autorizada, pois sua irônica diferença se estabelece no próprio âmago da semelhança" (HUTCHEON, 1991, p. 95, grifos da autora); ainda segundo a especialista:

A paródia é, pois, na sua irónica "transcontextualização" e inversão, repetição com diferença. Está implícita [um distanciamento] crítico entre o texto fundo

\footnotetext{
${ }^{10}$ Marca-se que "Bakhtin ampliou o sentido da paródia e tornou obsoletas as definições stricto sensu do tipo «imitação cómico-burlesca», ao criar a noção de dialogismo (que desemboca na noção de texto como produção) e ao mostrar que a paródia é um discurso que dialoga com outro, mas que o faz com um sentido crítico, replicandoo e não reverenciando-o, como outros tipos de discurso o fazem [...]. O uso amplo do conceito de paródia, lançado por Bakhtin, encontrou irrestrito apoio da prática artística contemporanêa que é contestatária e paródica por excelência, o que se pode observar desde as primeiras realizações das vanguardas dos anos [...] vinte, do novecentos, até mesmo à chamada pós-modernidade" (RODRIGUES, 2002, p. 240).
} 
[hipotexto] a ser parodiado e a nova obra que incorpora [hipertexto], distância geralmente assinada pela ironia (HUTCHEON, 1989, p. 48).

As concepções de paródia recuperadas dos críticos confluem, assim, aos desdobramentos analíticos contemplados neste artigo com o seguinte entendimento: além de parodiar a si mesma, sitiar o seu texto à uma "tendência apreciada ou dominante", Clarice Lispector apropria-se de ícones relativos ao Antigo Testamento, marcados no capítulo seis do livro de Isaías, para realçar "a teimosa" Lucrécia Neves: a falta de conhecimento, a inaptidão para o esclarecimento. Nesse veio, a autora, ao erguer em seu discurso o texto bíblico, o faz de forma paralela, com acentuada diferença.

Compete, por sua vez, transcrever os versos grafados no livro bíblico:

E aconteceu no ano em que morreu o rei Uzias que vi o Senhor sentado num trono, alto, elevado, e a casa ficou cheia da glória d'Ele. E serafins estavam à volta d'Ele: um tinha seis asas e um tinha seis asas [ou seja, cada um tinha seis asas]. Com duas cobriam o seu rosto; e com duas cobriam os seus pés; e com duas voavam (ISAÍAS, 6:1-2).

E eu disse: "Ai de mim! Porque fiquei pasmado! Pois sendo um ser humano com lábios impuros, vivo entre um povo de lábios impuros! E vi o Rei, o Senhor Sabaoth, com os meus olhos!". ${ }^{12}$

Então me foi enviado um dos serafins. E tinha na mão um carvão vivo que com uma tenaz ele tirara do altar. E tocou na minha boca e disse: "Eis que isto tocou os teus lábios e removerá os teus desregramentos e purificará os teus erros". Então ouvi a voz do Senhor, dizendo: "Quem enviarei? Quem irá ter com este povo?”. E eu disse: “Eis que sou eu! Envia-me!” (ISAÍAS 6: 5-8).

Esses trechos marcam o chamado da personagem bíblica para tornar-se profeta; circunstância que pressupõe a santificação de Isaías subordinada ao fogo que foi retirado do altar, representado na escritura sagrada como um carvão vivo, em chamas, que a um dos dois serafins coube encostar em seus lábios. Santificado com esta coloração, evidentemente mística, em que o homem comum se reveste de autoridade e se dispõe a apregoar a verdade divina, Isaías, agora profeta, pode, então, transmitir a mensagem imposta por Deus, advertindo e censurando o seu povo.

\footnotetext{
${ }^{11}$ O advérbio "teimosamente", posto no romance de Clarice Lispector, conforme interpretação de Bernadete GrobLima, "alude à oposição de Lucrécia Neves às mudanças" (GROB-LIMA, 2009, p. 108).

12 As citações bíblicas do livro de Isaías e do livro de Oseias foram transpostas da Bíblia Volume III: Antigo Testamento: os livros proféticos. Tradução de Frederico Lourenço. 1. ed. São Paulo: Companhia das Letras, 2019. 
Compete esclarecer que em contexto bíblico "as palavras hebraicas qadosh, "santo"; qodesh, "santidade; e as palavras gregas hagios e hagiosyne significam basicamente a separação do que é comum ou impuro, e a consagração a Deus" (DICIONÁRIO BÍBLICO WYCLIFFE, p. 1760).

A incorporação da passagem de Isaías, de um estado a outro, na obra de Clarice Lispector, tem seu registro de forma modificada conforme os desdobramentos que abaixo são considerados. O quarto capítulo "A estátua pública" materializa sua rude e limitada personagem, Lucrécia Neves, "inventando", em linguagem que "articula seus pensamentos numa retórica completamente teatral” (GROB-LIMA, 2009, p. 74), com pena de avestruz em suas mãos, a ação de receber uma notícia que não a satisfaz:

Um homem apareceu e a água escorria de sua capa. Quando pensou que ele nunca falaria, o visitante disse sobre a barba ensopada:

- Chegou, Lucrécia. Já chegou o navio! [...].

- Bem carregado?

- Sempre o mesmo. Carvão. Sempre carvão.

Lucrécia Neves mantinha-se retesada.

- Pode ir então, disse-lhe com os olhos cheios de lágrimas frias, pode ir, não interessa.

Não era esse o carregamento, não era esta a notícia! (LISPECTOR, 2019, p. $71)$.

O carregamento de carvão, frio, isto é, em seu estado bruto, recupera, simbolicamente, a temperatura das lágrimas de Lucrécia, igualmente frias. Sendo, pois, o carvão, "símbolo das forças ocultas e secretas; o carvão negro e frio necessita de uma centelha para fazer despertar nele as energias adormecidas" (HERDER LEXICON, 1998, p. 47). Nesse direcionamento, a vivacidade, quer seja no mineral, quer seja na condição humana da protagonista, é posta em declínio: não há fogo - (elemento fundamental à configuração da validação do chamado de Isaías) - e se não há fogo, não existe, consequentemente, espaço para a ampliação da autoconscientização, do entendimento, uma vez que, "assim como o sol, pelos seus raios, o fogo simboliza por suas chamas o intelecto, a ação fecundante, purificadora e iluminadora" (CHEVALIER; GHEERBRANT, 1994, p. 440).

Materializada dentro de uma composição cênica em que a abundante chuva se instala no exterior da casa da personagem, sua repercussão, por outro lado, é associada ao interior do ambiente e, por consequência, ao perfil "gelado" da protagonista. O texto, ao descrever a casa 
e seus objetos, atém-se a descrever a umidade, o frio e a escuridão: "o que era de madeira estava úmido e os metais gelados [...], apagadas as últimas luzes” (LISPECTOR, 2019, p. 79).

Destaca-se que ao contrário da representatividade que ao carvão é projetada na passagem bíblica, no enredo clariciano seu registro é opaco, permanece gélido, sem vivacidade, é apenas "o de sempre", representação do ramerrão em que a mulher se adequa: apagado, ininteligível, e por consequência, sitiado.

Por sua vez, o fluxo narrativo objetivando apresentar Lucrécia à metáfora da estátua existente na praça da cidade, por isso o título do capítulo "A estátua pública", registra a personagem ouvindo o barulho de asas de uma pomba: "Ergue-se sonolenta até a janela, e de fato, no instante em que tocava o parapeito, ouviu o barulho de asas. Da varanda invisível ao lado ergue-se a pomba espavorida no meio da chuva e em voo desapareceu" (LISPECTOR, 2019, p. 72). Um símbolo que à pomba é instituído em contexto bíblico, dentre as concepções interpretativas existentes, relaciona-se à ignorância como caracterização efetiva da ave: "E Efraim era como uma pomba, sem inteligência e sem coração. Chamava pelo Egito; E eles dirigiam-se aos assírios" (OSEIAS, 7:11). ${ }^{13}$ Nessa confluência, a personagem clariciana, em descompasso com a possibilidade de iluminosas epifanias, presa à ignorância, compactua, metaforicamente, à equiparação da ave grafada no livro bíblico acima referenciado.

Contudo, na página que dá sequência ao registro do voo da pomba, a materialidade de Lucrécia Neves, condicionada à voz narrativa, é marcada por uma suposta postura de autoconscientização de ser e estar no mundo (mundo metaforicamente associado à cidade de São Geraldo). Isto porque a personagem é grafada quase que a tomar consciência da renovação simbólica atrelada a chuva que cai sobre a cidade, isto é, a possibilidade de esvair-se do conformismo, fluir em novos e ilimitados posicionamentos. Mas o aclaramento não se sustenta no discurso. O narrador evidencia a visível limitação que Lucrécia tem para refletir acerca de si e de sua posição imposta socialmente.

Procurando "prender-se à primeira salvação sólida", a personagem tem sua visão direcionada a espiar seu mundo pelo "confuso buraco da fechadura" (LISPECTOR, 2019, p.

\footnotetext{
13 A contrapelo da definição depreciativa acerca da pomba no livro de Oséias, registro que dialoga com as características de Lucrécia, marca-se alguns exemplos positivos que a ave representa em contexto bíblico "Noé solta três pombas após o Dilúvio e uma delas volta com um ramo de oliveira; [a pomba] tornou-se o signo de conciliação com Deus e, desde então, símbolo de paz. Além disso, a pomba branca simboliza a simplicidade e a pureza, e sobretudo na iconografia cristã, o Espírito Santo" (HERDER LEXICON, 1998, p. 162). Destituída destas projeções de beleza, materializada em adequação às características de Lucrécia Neves, a ave no texto de Clarice pode ser entendida como mais um elemento simbólico a representar a antiepifania.
} 
73), nesse enquadramento, a antiepifania, o aborto epifânico, a fuga da experiência iluminosa acontece, e à Lucrécia a inclusão no aspecto limitado e engessado se perpetua. "Mais lúcida [...] ela que se aproximara tanto que por um instante tivera medo de ser santificada - pela realidade?" (LISPECTOR, 2019, p. 72).

Nota-se que o possível aclaramento de Lucrécia Neves com relação a sua condição prisional é, para ela, segundo a voz narrativa, uma grande aproximação para um novo estado de vida, que, no entanto, regride em sua efetiva realização. A santificação, isto é, a conscientização de ser separada dos muros sitiados de sua presente condição, "mulher sitiada", é grafada na interrogativa - "pela realidade?" - pondo em descrédito e em impossibilidade a superação do seu mundo real, empírico, paralisado. Lucrécia permanece santificada pela imobilidade, separada pela falta de conhecimento. Ocorrência que, ao esvaziar a vitalidade simbólica da aproximação da personagem ao entendimento, sua "muda existência" (LISPECTOR, 2019, p. 64), seu posicionamento complacente com a insuficiente inteligência, repercute em outro dos seus cinco sentidos: a personagem "perdera enfim o dom da fala" (LISPECTOR, 2019, p. 75).

Lucrécia, muda e míope, caracteriza-se ainda mais à estátua pública, inclusive na forma como a personagem é moldada à "visão masculina" da cidade sitiada:

Um homem passou e a olhou: ela teve a impressão de que ele a vira estreita e alongada, com um chapéu pequeno demais: como num espelho. Bateu perturbada as pálpebras, embora não soubesse que forma escolheria ter; mas o que o homem vê é uma realidade. E sem sentir a moça tomou a forma que o homem percebera nela (LISPECTOR, 2019, p. 46).

Na posição em que estava, Lucrécia Neves poderia mesmo ser transportada à praça pública. Faltavam-lhe apenas o sol e a chuva. Para que, coberta de limo, fosse enfim desapercebida pelos habitantes e enfim vista inconscientemente. Porque era assim que uma estátua pertencia a uma cidade (LISPECTOR, 2019, p. 76).

E é nessa conjuntura que Lucrécia Neves, de fato, pertence à cidade de São Geraldo, assim, também, como a cidade pertence à personagem. ${ }^{14}$ Essa condição, pois, recupera a marca social que a voz narrativa acentua para "a mulher sitiada" à sociedade na qual a insere: o escape ilusório do ramerrão dos seus dias condicionado ao casamento. Nesse veio, a personagem, cega, "na escuridão" na qual se perfila viver, "velava cheia de sono, sonhando em se casar" (LISPECTOR, 2019, p. 79).

\footnotetext{
${ }^{14}$ Registre-se que no sexto capítulo do romance, "Esboço da cidade", a voz narrativa enfatiza o entrelaçamento de Lucrécia Neves para com a cidade: "Se não pudera atravessar os muros da cidade, pelo menos fazia agora parte desses muros, em cal, pedra e madeira" (LISPECTOR, 2019, p. 101).
} 
O drama da linguagem, para usar a expressão alcunhada por Benedito Nunes, é assinalado na narrativa de Clarice Lispector com ambivalentes enunciações: ao dramatizar ficcionalmente o discurso comum que marca a vida social da mulher da década de 1940, isto é, o discurso que apontava ao destino de ser mulher à marital condição (donas de casas e mães), o texto sitiado de Clarice deixa-se harmonizar com essa estruturação, mas a questiona, ironicamente, por configurar sua protagonista destituída de conhecimento, inapta à autoconscientização. Além disto, utilizando-se do discurso patriarcal, para questioná-lo por meio de uma linguagem linear e em certa medida caricata, Clarice critica com sutil ironia, na própria estrutura e temática do romance, em produção atípica dentro do conjunto de sua obra, as críticas que recebeu de seus primeiros intérpretes.

Voltando a atenção ao aspecto religioso que se configura em $A$ cidade sitiada, a incompletude de Lucrécia Neves ganha maiores proporções inclusive à apropriação da voz narrativa dos temas pontuados no livro profético de Isaías. Ao amoldamento das percepções decepcionantes que o narrador constrói à caracterização da personagem, a regência divergente, isto é, a apropriação assinalada pela paródia do texto sagrado, esculpe a protagonista, - se vista de três quartos - como um serafim coxo.

Tão fútil e fraca, tão insignificante, aproveitamento a mão que estava às costas para afastar uma vespa [...]. E eis que de perfil, a bocejar, parecia o anjo que sopra na porta das igrejas. Entre menina e menino, o olho, já piscando de sono, a espiar de perfil.

Embora vista de três quartos ganhasse de súbito volume e sombras, delicadeza e opulência: um serafim coxo (LISPECTOR, 2019, p. 76, grifo nosso).

O diálogo entre o texto clariciano com o texto profético é assinalado e validado em transposição literária porque a figura dos serafins, conforme antecipado, é exclusiva do Antigo Testamento, materializada apenas no livro de Isaías. A intertextualidade existente, entretanto, afigura-se a transgredir o texto sacrílego. Ocorrência que, ao invés de ridicularizar o hipotexto, depreciando suas temáticas, marca-se ao lado dele, numa tensão crítica, ampliando sua significação, direcionando-a à esfera limitada da protagonista Lucrécia.

A figura de um serafim coxo convoca para o estado existencial da protagonista a metáfora que materializa seu descompasso e esvaziamento das percepções iluminadoras, seu construto não purificado da ignorância. Contudo, se por um lado a referência ao serafim, mesmo que imperfeito, assegura a condição angelical do ícone aludido, essa inferência marca ainda o fato da personagem clariciana ser desprovida de inteligência, mas ter "um excedente de beleza" (LISPECTOR, 2019, p. 33). 
O sobrenatural místico - marca epifânica - atribuído às figuras dos serafins, seres transmissores da pureza e do conhecimento, tem seu sentido esvaído no texto de Clarice Lispector. É o símbolo da pomba, eivado de desinteligência, que, repercute e se materializa no romance. Alusão que centraliza o diálogo com o verso suprarreferenciado do livro do profeta Oseias, e desvia a simbologia de pureza e inteligência condicionada ao capítulo seis do livro do profeta Isaías. Desvio que alcança não apenas o cerne da protagonista da história de Clarice Lispector, mas a própria cidade representada, São Geraldo. Cidade e cidadã alienadas dentro de seus muros.

Sintetizam-se, portanto, as análises estendidas neste estudo com os seguintes direcionamentos: se no texto bíblico os lábios do profeta são purificados a fim de promover a concretude de sua fala, sua voz que em profecia será propagada, no texto de Clarice, a irônica repetição com diferença se estabelece na mudez que à Lucrécia Neves o texto direciona: "a personagem perde o dom da fala" (LISPECTOR, 2019, p. 75), e, por consequência, mantém-se à incompreensão em que é configurada e projetada no discurso narrativo.

Os elementos sagrados, as figuras bíblicas na obra analisada, possibilitam, na readequação e na transgressão que a autora faz do texto hierático, um molde que aguenta e sustenta as características de Lucrécia Neves, isto é, sua adequação na futilidade e, por consequência, sua permanência na alienação de sua opaca e engessada percepção da vida, esvaziada de entendimento.

Com essa mesma configuração, isto é, sitiado, o texto lançado em 1949 é registro crítico da própria escritora - Clarice Lispecor - concernente leituras de especialistas que, ao analisarem suas duas primeiras obras, marcaram a impossibilidade de a escritora construir um romance no molde tradicional, como era caracterizada a maior parte da produção literária do decênio acima referenciado. Interpretação que reivindica para "o romance sitiado", dentro do conjunto da obra de sua autora, a leitura apreciativa que considera na materialidade do texto lispectoriano uma postura intencionalmente direcionada ao cerceio da expressão pessoal e social.

\section{Referências}

CHEVALIER, Jean; GHEERBRANT, Alain, Dicionário de Símbolos (mitos, sonhos, costumes, gestos, formas, figuras, cores, números). Tradução Vera da Costa e Silva [et. Al.]. Rio de Janeiro: José Olympio, 1994.

COUTINHO, Edilberto. Uma mulher chamada Clarice Lispector. O Globo. Rio de Janeiro, 29 abr. 1976; republicado em Criaturas de Papel. Rio de Janeiro/Brasília, Civilização Brasileira/INL, 1980, p. 165-170. 
COMPAGNON, Antoine. O demônio da teoria: literatura e senso comum. Tradução de Cleonice Paes Barreto Mourão e Consuelo Fortes Santiago. 2. ed. Belo Horizonte: Editora da UFMG, 2010.

Dicionário Bíblico Wycliffe. Tradução Degmar Ribas Júnior. 2. ed. Rio de Janeiro: CPAD, 2007.

GENETTE, Gérad. Palimpsestos: a literatura de segunda mão. Tradução Cibele Braga et al. Belo Horizonte: Viva a Voz, 2010.

GOTLIB. Nádia Battella. O romance inaugural. In: LISPECTOR, Clarice. Perto do coração selvagem. 1. ed. Rio de Janeiro. Rocco, 2019.

Clarice: uma vida que se conta. 6. ed. rev. e aum. São Paulo: Editora da Universidade de São Paulo, 2009.

Macabéa e as mil pontas de uma estrela. In: Personae - Grandes personagens da literatura brasileira. Org. Benjamin Abdala Junior; Lourenço Dantas Mota. 1. ed. São Paulo: SENAC, 2001.

GROB-LIMA, Bernadete. O percurso das personagens de Clarice Lispector. Rio de Janeiro: Garamond, 2009.

GUIDIN, Márcia Lígia. Uma biografia pop: nova edição de livro sobre vida e obra de Clarice Lispector segue repleta de equívocos defendidos por Benjamin Moser. Jornal Rascunho, n. 212, Curitiba, dezembro de 2017.

HELENA, Lucia. Nem musa, nem medusa: itinerários da escrita em Clarice Lispector. 3. ed. revista e ampliada. Niterói: Editora da UFF, 2010, p. 98.

HERDER LEXICON. Dicionário de símbolos. Tradução Erlon José Paschoal. São Paulo: Cultrix, 1998.

HUTCHEON, Linda. Poética do pós-modernismo: história, teoria, ficção. Tradução de Ricardo Cruz. Rio de Janeiro: Imago Editora, 1991.

Uma teoria da paródia: ensinamentos das formas de arte do século XX. Trad. Teresa Louro Pérez. Lisboa: Edições 70, 1989.

JERONIMO, Thiago Cavalcante. Benjamin Moser: quando a luz dos holofotes interessa mais que a ética acadêmica. DLCV, Revista de Língua, Linguística e Literatura, v. 14, n. 1, João Pessoa: UFPB, 2018.

LISPECTOR, Clarice. A cidade sitiada. Rio de Janeiro: Rocco, 2019.

A paixão segundo G. H. Rio de Janeiro, Rocco, 2014.

A descoberta do mundo. Lisboa: Indícios de Oiro Edições, 2004. 
. A descoberta do mundo. Rio de Janeiro: Rocco, 1999.

. As palavras de Clarice Lispector. Curadoria de Roberto Corrêa dos Santos. 1. ed. Rio de Janeiro: Rocco, 2013.

O tempo de Clarice Lispector. Curadoria de Roberto Corrêa dos Santos. 1. ed. Rio de Janeiro: Rocco, 2014.

LOURENÇO, Frederico. Bíblia Volume III: Antigo Testamento: os livros proféticos. Tradução de Frederico Lourenço. 1. ed. São Paulo: Companhia das Letras, 2019.

MOISÉS, Massaud. Dicionário de termos literários. 12 ed. rev. e ampl. São Paulo: Cultrix, 2004.

NUNES, Benedito. O drama da linguagem: uma leitura de Clarice Lispector. São Paulo: Editora Ática, 1995.

PAULINO, Simone. Como Clarice Lispector pode mudar sua vida. 1. ed. São Paulo: Buzz Editora, 2017.

PICCHIO, Luciana Stegagno. Epifania de Clarice. Revista Remate de males, Campinas, n. 9, p. 17-29, 1989.

PIMENTA, Paulo Emílio. As origens do fenômeno religioso: segundo a história, a ciência e a filosofia. Belo Horizonte: Ed. São Vicente, 1980.

PIÑON, Nélida. Na Berlinda: Clarice e a Amiga” in: Caderno Feminino, 5 Caderno, Correio da manhã. Ed. 21457, Rio de Janeiro, 1963, p. 7. Disponível em: http://memoria.bn.br/DocReader/cache/2127909818842/I0037967-

$\underline{00 \mathrm{Alt}=000579 \mathrm{Lar}=000347 \mathrm{LargOri}=004440 \mathrm{AltOri}=007398 . J P G}$. Acesso em: 17.03 .2020 .

RODRIGUES, Selma Calazans. "Canto/Contracanto: a paródia" in: Revista de Humanidades e Tecnologias: Dossiê Línguas e Culturas. Lisboa: Edições Universitárias Lusófonas, 2002.

SÁ, Olga de. A escritura de Clarice Lispector. Petrópolis: Vozes; Lorena: Faculdades Integradas Teresa D’Ávila, 1979.

Clarice Lispector: a travessia do oposto. São Paulo: Annablume, 1993.

SANT'ANNA, A. R. O ritual epifânico do texto. In: SANT'ANNA, A. R; COLASANTI, M. Com Clarice. 2013, p. 128.

SOUSA, Carlos Mendes de. Clarice Lispector: pinturas. Rio de Janeiro: Rocco, 2013. 